\title{
Comparative Efficacy of Combination Therapy of Ipilimumab Plus Nivolumab for Non-clear Cell Renal Cell Carcinoma
}

\author{
YUKARI BANDO, JUNYA FURUKAWA, YASUYOSHI OKAMURA, TAKUTO HARA, \\ TOMOAKI TERAKAWA, YUZO NAKANO and MASATO FUJISAWA \\ Department of Urology, Kobe University Graduate School of Medicine, Kobe, Japan
}

\begin{abstract}
Background/Aim: The survival benefit of immune checkpoint inhibitors for non-clear cell renal cell carcinoma (nccRCC) is unclear. Our purpose was to evaluate the real-world survival benefit of ipilimumab plus nivolumab retrospectively. Patients and Methods: We retrospectively reviewed medical records of 33 patients with metastatic nccRCC who received combination therapy with ipilimumab plus nivolumab or monotherapy with a molecular targeted agent as initial systemic therapy. Progression-free survival (PFS), overall survival (OS) and objective response rate were compared between the two groups. Results: Median PFS of each therapy was 3.5 and 4.7 months $(p=0.61)$ and median OS was 19.6 and 10.6 months $(p=0.23)$, respectively. Three patients treated with ipilimumab and nivolumab had a complete response, resulting in an objective response rate of $30.0 \%$, while that for molecular targeted therapy was $4.5 \%(p=0.04)$. Conclusion: Ipilimumab plus nivolumab achieved statistically non-significant, but longer overall survival and significantly higher objective response rate.

During the last decade, phase III clinical trials of immune checkpoint inhibitors (ICIs) have yielded significantly improved treatment outcomes of patients with renal cell carcinoma (1-4). Consequently, several combination therapies including ICIs have been widely adopted for renal cell carcinoma $(5,6)$. After the CheckMate 214 trial, combination therapy with nivolumab plus ipilimumab became a mainstay of treatment of intermediate- or poor-risk renal cell carcinoma because overall survival (OS) benefit was maintained after $>4$ years' follow-up (7).
\end{abstract}

This article is freely accessible online.

Correspondence to: Yukari Bando, MD, Ph.D., Department of Urology, Kobe University Graduate School of Medicine, 7-5-1 Kusunoki-cho, Kobe, 650-0017, Japan. Tel: +81 783826155, Fax: +81 783826169, e-mail: ykrbando@med.kobe-u.ac.jp

Key Words: Non-clear cell renal cell carcinoma, immune checkpoint inhibitor.
However, patients with non-clear cell renal cell carcinoma (nccRCC) were excluded from most clinical trials that included ICIs (8). Therefore, the benefit of ICIs compared to molecular targeted therapy in nccRCC remains uncertain. Consequently, molecular targeted therapy remains the leading recommendation for initial treatment of nccRCC (5, 6). Several retrospective studies have indicated efficacy of combination therapy with ipilimumab and nivolumab in nccRCC (9-11).

The aim of this study was to evaluate the survival benefit of combination therapy with ipilimumab plus nivolumab compared to molecular targeted therapy in patients with nccRCC.

\section{Patients and Methods}

This study was conducted under Institutional Review Board approval of the Kobe University Hospital (approval No. B210089). We retrospectively reviewed the medical records of 33 patients with metastatic nccRCC at Kobe University Hospital between April 2008 and December 2020. Patients who received nivolumab monotherapy as subsequent systemic therapy during follow-up were also included in the patient group of molecular targeted therapy. Baseline clinical data including age, gender, body mass index, ethnic origin, Karnofsky performance status, prior nephrectomy status, primary histology, metastatic sites, and laboratory data were collected by reviewing patient medical records. Treatment outcomes, including best response [assessed by RECIST 1.1 (12)], time to treatment failure, progression-free survival (PFS), OS, and adverse effects retrieved from medical records were evaluated according to the nature of initial systemic therapy.

All statistical analyses were performed with JMP 12.0 (SAS Institute Inc, Cary, NC, USA), using $p<0.05$ to indicate significant results. PFS and OS were estimated with Kaplan-Meier curves, and differences were analysed by log-rank test.

\section{Results}

The clinicopathological characteristics of eligible patients are listed in Table I. The median age of eligible patients was 65 years, and there were 24 men (72.7\%) and 9 women (27.3\%). Prior definitive surgical therapy had been performed in 26 
Table I. Characteristics of eligible patients.

\begin{tabular}{|c|c|c|c|c|}
\hline & IN $(\mathrm{N}=10)$ & $\operatorname{MTT}(\mathrm{N}=23)$ & Total $(\mathrm{N}=33)$ & $p$-Value \\
\hline Age (median, IQR) & $60(44-70)$ & $67(60-71)$ & $65(58-71)$ & 0.07 \\
\hline Male/Female $(\%)$ & $8(80.0 \%) / 2(20.0 \%)$ & $16(69.6 \%) / 7(30.4 \%)$ & $24(72.7 \%) / 9(27.3 \%)$ & 0.53 \\
\hline \multicolumn{5}{|l|}{ Karnofsky performance status } \\
\hline$\geq 80 \%$ & $7(70.0 \%)$ & $21(91.3 \%)$ & $28(84.8 \%)$ & \multirow[t]{2}{*}{0.13} \\
\hline$<80 \%$ & $3(30.0 \%)$ & $2(8.7 \%)$ & $5(15.2 \%)$ & \\
\hline \multicolumn{5}{|l|}{ Prior nephrectomy } \\
\hline Yes & $6(60.0 \%)$ & $20(87.0 \%)$ & $26(78.8 \%)$ & \multirow[t]{8}{*}{0.09} \\
\hline \multicolumn{4}{|l|}{ Histological type } & \\
\hline Papillary & $3(30.0 \%)$ & $11(47.8 \%)$ & $14(42.4 \%)$ & \\
\hline Unclassified & $3(30.0 \%)$ & $4(17.4 \%)$ & $7(21.2 \%)$ & \\
\hline Collecting duct & $0(0 \%)$ & $4(17.4 \%)$ & $4(12.1 \%)$ & \\
\hline Translocation associated & $2(20.0 \%)$ & $2(8.7 \%)$ & $4(12.1 \%)$ & \\
\hline Spindle cell & $1(10.0 \%)$ & $2(8.7 \%)$ & $3(9.1 \%)$ & \\
\hline Chromophobe & $1(10.0 \%)$ & $0(0 \%)$ & $1(3.0 \%)$ & \\
\hline Existence of sarcomatoid differentiation & $2(20.0 \%)$ & $3(13.0 \%)$ & $5(15.2 \%)$ & 0.62 \\
\hline \multicolumn{5}{|l|}{ Number of metastatic sites } \\
\hline 1 & $5(50.0 \%)$ & $15(65.2 \%)$ & $20(60.6 \%)$ & \multirow[t]{3}{*}{0.17} \\
\hline 2 & $4(40.0 \%)$ & $5(21.7 \%)$ & $9(27.3 \%)$ & \\
\hline$\geq 3$ & $1(10.0 \%)$ & $3(13.0 \%)$ & $4(12.1 \%)$ & \\
\hline \multicolumn{5}{|l|}{ Sites of metastases } \\
\hline Lymph node & $3(30.0 \%)$ & $7(30.4 \%)$ & $10(30.3 \%)$ & \\
\hline Lung & $6(60.0 \%)$ & $11(47.8 \%)$ & $17(51.5 \%)$ & \\
\hline Bone & $5(50.0 \%)$ & $3(13.0 \%)$ & $8(24.2 \%)$ & \\
\hline Liver & $0(0 \%)$ & $4(17.4 \%)$ & $4(12.1 \%)$ & \\
\hline \multicolumn{5}{|l|}{ IMDC risk classification } \\
\hline Favorable & $0(0 \%)$ & $3(13.0 \%)$ & $3(9.1 \%)$ & \multirow[t]{3}{*}{0.18} \\
\hline Intermediate & $3(30.0 \%)$ & $10(43.5 \%)$ & $13(39.4 \%)$ & \\
\hline Poor & $7(70.0 \%)$ & $10(43.5 \%)$ & $17(51.5 \%)$ & \\
\hline \multicolumn{5}{|l|}{ Laboratory data } \\
\hline Hemoglobin (g/dl) (median, IQR) & $11.4(9.2-12.6)$ & $10.8(9.5-13.1)$ & $10.9(9.5-13.1)$ & 0.81 \\
\hline Platelet count $\left(10^{4} / \mathrm{ml}\right)$ (median, IQR) & $35.0(27.2-45.4)$ & $25.3(18.3-35.6)$ & $27.4(19.5-41.0)$ & 0.06 \\
\hline Neutrophil-lymphocyte ratio (median, IQR) & $4.6(2.1-8.1)$ & $2.8(2.3-6.4)$ & $3.6(2.2-7.5)$ & 0.58 \\
\hline Corrected Ca (mg/dl) (median, IQR) & $9.5(9.1-9.9)$ & $9.5(9.2-10.0)$ & $9.4(9.2-10.0)$ & 0.35 \\
\hline $\mathrm{CRP}(\mathrm{mg} / \mathrm{dl})($ median, IQR) & $3.8(0.1-7.9)$ & $0.61(0.1-4.3)$ & $1.6(0.1-4.4)$ & 0.31 \\
\hline
\end{tabular}

IQR, Interquartile range; IMDC, International Metastatic RCC Database Consortium; CRP, C-reactive protein; IN, ipilimumab and nivolumab; MTT, molecular targeted therapy.

patients (78.8\%). Regarding histological subtypes, 14 (42.4\%) patients were diagnosed as papillary, $7(21.2 \%)$ as unclassified, $4(12.1 \%)$ as collecting duct, $4(12.1 \%)$ as translocation associated, $3(9.1 \%)$ as spindle cell, and $1(3.0 \%)$ as chromophobe renal cell carcinoma. Five patients (15.2\%) were diagnosed as having sarcomatoid differentiation. Common sites of metastases were lymph nodes (10 patients, 30.3\%), lung (17, $51.5 \%)$, bone $(8,24.2 \%)$ and liver $(4,12.1 \%)$. Three patients $(9.1 \%)$ were classified into the favourable-risk group, 13 $(39.4 \%)$ were in the intermediate-risk group, and $17(51.5 \%)$ were in the poor-risk group according to International Metastatic RCC Database Consortium prognostic assessments.

Treatment outcomes are summarized in Table II. Ten patients were administered ipilimumab plus nivolumab as initial systemic therapy. Twenty-three patients were administered a molecular targeted agent as initial systemic therapy: $11(47.8 \%)$ received sunitinib, 2 (8.7\%) sorafenib, $1(4.3 \%)$ pazopanib and $9(39.1 \%)$ temsirolimus. The median time to treatment failure with ICIs and molecular targeted therapy was 2.4 and 5.0 months, respectively $(p=0.16)$. Median PFS for treatment with ICIs and molecular targeted agent was 3.5 and 4.7 months, respectively ( $p=0.61$ ) (Figure 1). Median OS of patients with initial systemic therapy of ICIs and molecular targeted agent was 19.6 and 10.6 months, respectively ( $p=0.23$ ) (Figure 2$)$.

The best treatment responses for each histological type according to initial systemic therapy are shown in Table III. Among 10 patients with initial systemic therapy with ICIs, complete response was confirmed in $3(30.0 \%)$, stable disease in $3(30.0 \%)$, and progressive disease in $4(40.0 \%)$. Two patients with papillary renal cell carcinoma and one with spindle cell renal cell carcinoma experienced complete 
Table II. Treatment outcomes of initial systemic therapy.

\begin{tabular}{|c|c|c|c|c|}
\hline Regimen of initial systemic therapy & IN $(\mathrm{N}=10)$ & $\operatorname{MTT}(\mathrm{N}=23)$ & Total $(\mathrm{N}=33)$ & $p$-Value \\
\hline Ipilimumab plus nivolumab & $10(100 \%)$ & - & $10(30.3 \%)$ & \\
\hline Sunitinib & & $11(47.8 \%)$ & $11(33.3 \%)$ & \\
\hline Sorafenib & & $2(8.7 \%)$ & $2(6.1 \%)$ & \\
\hline Pazopanib & & $1(4.3 \%)$ & $1(3.0 \%)$ & \\
\hline Temsirolimus & & $9(39.1 \%)$ & $9(2.7 \%)$ & \\
\hline \multicolumn{5}{|l|}{ Treatment outcomes } \\
\hline Follow-up period (months, range) & $13(1.3-35.3)$ & $10.6(1.1-78.9)$ & 11.7 & \\
\hline Median overall survival (months) & 19.6 & 10.6 & 12.6 & 0.23 \\
\hline Median time to treatment failure (months) & 2.4 & 5.0 & 4.3 & 0.16 \\
\hline Median progression-free survival (months) & 3.5 & 4.7 & 4.5 & 0.61 \\
\hline \multicolumn{5}{|c|}{ Reason of discontinuation of initial systemic therapy } \\
\hline Progression disease & $5(50.0 \%)$ & $18(78.3 \%)$ & $23(69.7 \%)$ & \\
\hline Adverse event & $3(30.0 \%)$ & $4(17.4 \%)$ & $7(21.2 \%)$ & \\
\hline Ongoing & $2(20.0 \%)$ & $0(0 \%)$ & $2(6.1 \%)$ & \\
\hline Others & $0(0 \%)$ & $1(4.3 \%)$ & $1(3.0 \%)$ & \\
\hline \multicolumn{5}{|c|}{ Completion of 4 cycles of ipilimumab plus nivolumab (\%) } \\
\hline Yes & $4(40.0 \%)$ & - & & \\
\hline
\end{tabular}

IN, Ipilimumab and nivolumab; MTT, molecular targeted therapy.

response. Among 23 patients with initial systemic therapy with a molecular targeted agent, partial response was confirmed in $1(4.3 \%)$, stable disease in 16 (69.5\%), and progressive disease in $5(21.7 \%)$. One patient who experienced a partial response was diagnosed as renal cell carcinoma, unclassified. The objective response rates for ICIs and molecular targeted therapy were $30.0 \%$ and $4.5 \%$, respectively ( $p=0.04)$.

All adverse events of initial systemic therapy are listed in Table IV. Six patients $(60.0 \%)$ who were administered ICIs and $21(91.3 \%)$ administered a molecular targeted agent experienced adverse events. Three patients (30.0\%) administered ICIs and two patients $(8.7 \%)$ who were administered a molecular targeted agent experienced grade $3 / 4$ adverse events. Five patients (50\%) who received ICIs experienced immune-related adverse events, and three of those $(60.0 \%)$ received systemic treatment with steroid.

\section{Discussion}

In this study, we retrospectively evaluated the efficacy of combination therapy with ipilimumab plus nivolumab as initial systemic treatment for nccRCC in comparison with molecular targeted therapy. Combination therapy with ipilimumab plus nivolumab achieved nonsignificant but longer OS and significantly higher objective response rate than molecular targeted therapy.

Several phase III clinical trials of first-line combination therapy including ICIs for renal cell carcinoma excluded patients with non-clear cell histological type, although most trials yielded an excellent treatment outcome (1-4). Clinical trials of combination therapy including ICIs targeting nonclear cell renal cell carcinoma are ongoing in phase II and promising interim results have been reported (13-15). Previous small retrospective studies have shown efficacy of combination therapy with ipilimumab and nivolumab for nccRCC (9-11). However, there are limited clinical data to evaluate whether combination of ipilimumab plus nivolumab is the optimal systemic treatment for nccRCC because all these studies were single-arm and did not measure OS (911). Our study showed that combination therapy using ICIs, compared to molecular targeted therapy, prolonged OS and improved objective response rate, although there was no significant difference in OS.

There are some hypotheses on the efficacy of ICIs for nccRCC. One hypothesis for the variable response is the difference in expression of programmed death ligand-1 (PDL1) in the different types of nccRCC. The extent to which PD-L1 is expressed on tumour cells is reported to be one predictor of efficacy of programmed death-1 (PD-1) blockade $(16,17)$. Some authors have reported that some patients with nccRCC have high levels of PD-L1 expression. One study examining 26 patients with renal cell carcinoma with sarcomatoid differentiation identified PD-1p tumourinfiltrating lymphocytes in $96 \%$ of cases and PD-L1p sarcomatoid cells in $54 \%$ of cases, with co-expression identified in 13 cases (18). However, there were limitations related to the assessment method and to the tumour heterogeneity. The variety of available tests and different methodologies for determining positivity of PD-L1 expression result in different positive rates (19). Furthermore, the expression of PD-L1 can change during 


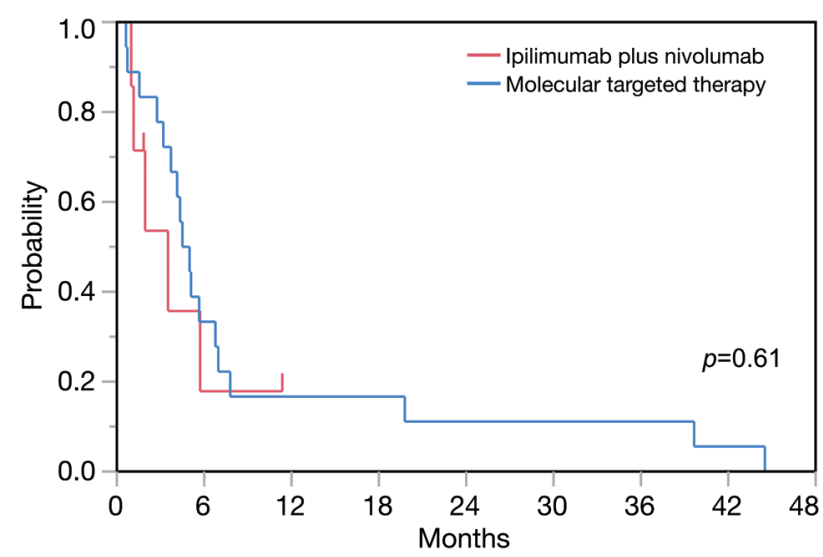

Figure 1. Progression-free survival according to initial systemic therapy (comparison between Ipilimumab plus nivolumab and molecular targeted therapy).

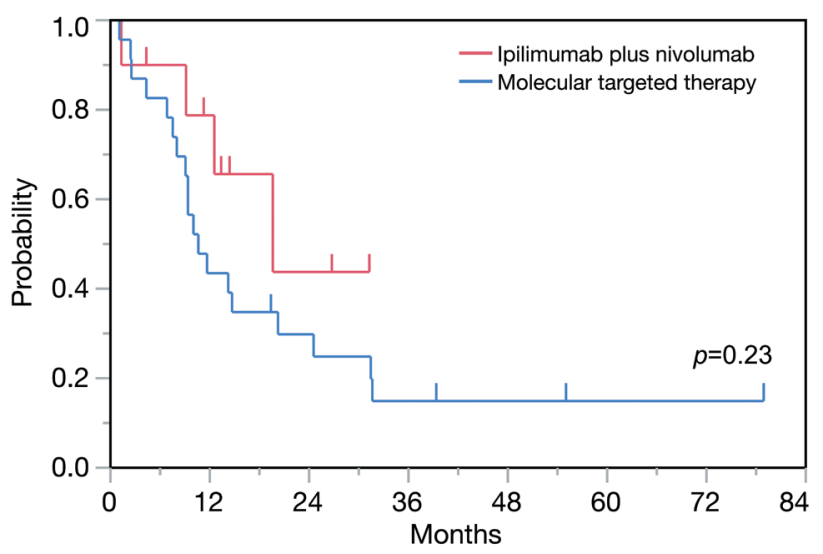

Figure 2. Overall survival according to initial systemic therapy (comparison between Ipilimumab plus nivolumab and molecular targeted therapy).

Table III. Best response of initial therapy.

\begin{tabular}{|c|c|c|c|c|c|c|}
\hline & \multirow[t]{2}{*}{ No. } & \multicolumn{5}{|c|}{ Best response } \\
\hline & & $\mathrm{CR}(\%)$ & PR (\%) & $\mathrm{SD}(\%)$ & $\mathrm{PD}(\%)$ & $\mathrm{N} / \mathrm{A}(\%)$ \\
\hline All & 33 & $3(9.1 \%)$ & $1(3.0 \%)$ & $19(57.6 \%)$ & $9(27.3 \%)$ & $1(3.0 \%)$ \\
\hline Ipilimumab and nivolumab & 10 & $3(30.0 \%)$ & $0(0 \%)$ & $3(30.0 \%)$ & $4(40.0 \%)$ & $0(0 \%)$ \\
\hline Papillary & 3 & $2(66.7 \%)$ & $0(0 \%)$ & $0(0 \%)$ & $1(33.3 \%)$ & $0(0 \%)$ \\
\hline Unclassified & 3 & $0(0 \%)$ & $0(0 \%)$ & $1(33.3 \%)$ & $2(66.7 \%)$ & $0(0 \%)$ \\
\hline Translocation associated & 2 & $0(0 \%)$ & $0(0 \%)$ & $1(50.0 \%)$ & $1(50.0 \%)$ & $0(0 \%)$ \\
\hline Spindle cell & 1 & $1(100 \%)$ & $0(0 \%)$ & $0(0 \%)$ & $0(0 \%)$ & $0(0 \%)$ \\
\hline Chromophobe & 1 & $0(0 \%)$ & $0(0 \%)$ & $1(100 \%)$ & $0(0 \%)$ & $0(0 \%)$ \\
\hline Molecular targeted therapy & 23 & $0(0 \%)$ & $1(4.3 \%)$ & $16(69.5 \%)$ & $5(21.7 \%)$ & $1(4.3 \%)$ \\
\hline Papillary & 11 & $0(0 \%)$ & $0(0 \%)$ & $9(81.8 \%)$ & $1(9.1 \%)$ & $1(9.1 \%)$ \\
\hline Unclassified & 4 & $0(0 \%)$ & $1(25.0 \%)$ & $2(50.0 \%)$ & $1(25.0 \%)$ & $0(0 \%)$ \\
\hline Collecting duct & 4 & $0(0 \%)$ & $0(0 \%)$ & $3(75.0 \%)$ & $1(25.0 \%)$ & $0(0 \%)$ \\
\hline Translocation associated & 2 & $0(0 \%)$ & $0(0 \%)$ & $1(50.0 \%)$ & $1(50.0 \%)$ & $0(0 \%)$ \\
\hline \multirow[t]{2}{*}{ Spindle cell } & 2 & $0(0 \%)$ & $0(0 \%)$ & $1(50.0 \%)$ & $1(50.0 \%)$ & $0(0 \%)$ \\
\hline & \multicolumn{2}{|c|}{ Ipilimumab+nivolumab } & \multicolumn{3}{|c|}{ Molecular targeted therapy } & $p$-Value \\
\hline Objective response rate & \multirow{2}{*}{\multicolumn{2}{|c|}{$30.0 \%$}} & \multicolumn{3}{|c|}{$4.5 \%$} & 0.04 \\
\hline Disease control rate & & & \multicolumn{3}{|c|}{$77.3 \%$} & 0.32 \\
\hline
\end{tabular}

CR, Complete response; PR, partial response; SD, stable disease; PD, progressive disease; N/A, not applicable. Statistically significant $p$-values are shown in bold.

tumour natural history or as a consequence of antineoplastic treatments. PD-L1 expression shows increased heterogeneity both intratumorally and between the primary tumour and distant metastases $(20,21)$. The second hypothesis comes from the immune microenvironment. ICIs activate immune pathways to induce T-cell-mediated tumour cell death (22). Accordingly, inflamed tumours that are highly infiltrated by tumour-reactive $\mathrm{T}$ cells, such as cytotoxic $\mathrm{T}$ lymphocytes, are more likely to respond to ICIs than are non-inflamed tumours (23). According to a meta-analysis, papillary renal cell carcinoma had a higher objective response rate to immune-checkpoint-based therapies (18.9\%) than chromophobe renal cell carcinoma did because the latter had a low number of immune infiltrates (23).

However, neither hypothesis can fully explain the efficacy of ICIs for treatment of nccRCC, and expression of PD-L1 
Table IV. Summary of adverse events.

\begin{tabular}{|c|c|c|c|c|}
\hline & \multicolumn{2}{|c|}{ Ipilimumab and nivolumab $(\mathrm{N}=10)$} & \multicolumn{2}{|c|}{ Molecular targeted therapy $(\mathrm{N}=23)$} \\
\hline & All grades & Grade 3-4 & All grades & Grade $3-4$ \\
\hline Any event & $6(60.0 \%)$ & $3(30.0 \%)$ & $21(91.3 \%)$ & $2(8.7 \%)$ \\
\hline Anemia & & & $2(8.7 \%)$ & $1(4.3 \%)$ \\
\hline Neutropenia & & & $2(8.7 \%)$ & $0(0 \%)$ \\
\hline Thrombocytopenia & & & $7(30.4 \%)$ & $0(0 \%)$ \\
\hline Hepatic failure & $2(20.0 \%)$ & $1(10.0 \%)$ & $1(4.3 \%)$ & $0(0 \%)$ \\
\hline Acute kidney injury & & & $2(8.7 \%)$ & $0(0 \%)$ \\
\hline Malaise & & & $2(8.7 \%)$ & $0(0 \%)$ \\
\hline Skin rash & $1(10.0 \%)$ & $0(0 \%)$ & $2(8.7 \%)$ & $0(0 \%)$ \\
\hline Mucositis oral & & & $4(17.4 \%)$ & $0(0 \%)$ \\
\hline Appetite loss & & & $1(4.3 \%)$ & $0(0 \%)$ \\
\hline Hand-foot syndrome & & & $3(13.0 \%)$ & $0(0 \%)$ \\
\hline Anaphylaxis & & & $1(4.3 \%)$ & $1(4.3 \%)$ \\
\hline Pneumonitis & $1(10.0 \%)$ & $1(10.0 \%)$ & $1(4.3 \%)$ & $0(0 \%)$ \\
\hline Hypopituitarism & $1(10.0 \%)$ & $1(10.0 \%)$ & & \\
\hline Adrenal insufficiency & $1(10.0 \%)$ & $1(10.0 \%)$ & & \\
\hline Hypothyroidism & $1(10.0 \%)$ & $0(0 \%)$ & $1(4.3 \%)$ & $0(0 \%)$ \\
\hline Any irAE & $5(50.0 \%)$ & $3(30.0 \%)$ & & \\
\hline Usage of steroid for irAE & $3(30.0 \%)$ & $3(30.0 \%)$ & & \\
\hline
\end{tabular}

irAE, Immune-related adverse event.

in eligible patients was not evaluated in our study. Further molecular studies are required to understand the oncogenic mechanisms of this heterogeneous group of tumours.

We reported several adverse events, including those requiring steroid treatment, after combination therapy with ipilimumab plus nivolumab. The frequency of grade $3 / 4$ adverse events was higher than that for molecular targeted therapy. However, it is equivalent or lower than that reported in the CheckMate 214 trial (1).

The present study had several limitations, including its retrospective nature and small sample size, resulting in differences between the two treatment groups. The percentage of patients with each histological subtype between the two treatment groups differed because nccRCC is a rare malignancy. The small sample size might have affected the outcome of this study because each tumour subtype harbours a distinct cell of origin and exhibits a distinct clinical behaviour that is expected to differentially affect responses to ICIs (24). The median follow-up of patients treated with combination of ipilimumab plus nivolumab was shorter than that of those treated with a molecular targeted agent. To evaluate the treatment outcome without these limitations, the results of prospective clinical trials, including SUNIFORECAST, of ipilimumab plus nivolumab are awaited (13). Furthermore, regarding subsequent therapy after initial therapy of immune checkpoint inhibitors, optimal second-line treatment strategy for nccRCC still remains unclear. There are limited clinical data though Japanese authors demonstrated anticancer activity of tyrosine kinase inhibitors after treatment of immune checkpoint inhibitors for nccRCC (25). In order to optimize the treatment strategy including second-line treatment for nccRCC, randomized clinical trial are awaited.

In conclusion, we confirmed that combination of ipilimumab plus nivolumab demonstrated better OS and objective response rate than a molecular targeted agent as initial systemic treatment of nccRCC. In the absence of available prospective data, this analysis aids selection of the initial systemic therapy for patients with nccRCC.

\section{Conflicts of Interest}

The Authors declare no conflicts of interest.

\section{Authors' Contributions}

Yukari Bando: Data curation, Writing and Original draft preparation. Junya Furukawa: Conceptualization, Methodology and Creation of research design. Yasuyoshi Okamura, Takuto Hara and Tomoaki Terakawa: Methodology and Investigation. Yuzo Nakano and Masato Fujisawa: Supervision.

\section{Acknowledgements}

We thank Cathel Kerr, BSc, PhD, from Edanz (https:// jp.edanz.com/ac) for editing a draft of this manuscript. 


\section{References}

1 Motzer RJ, Tannir NM, McDermott DF, Arén Frontera O, Melichar B, Choueiri TK, Plimack ER, Barthélémy P, Porta C, George S, Powles T, Donskov F, Neiman V, Kollmannsberger CK, Salman P, Gurney H, Hawkins R, Ravaud A, Grimm MO, Bracarda S, Barrios CH, Tomita Y, Castellano D, Rini BI, Chen AC, Mekan S, McHenry MB, Wind-Rotolo M, Doan J, Sharma P, Hammers HJ, Escudier B and CheckMate 214 Investigators: Nivolumab plus ipilimumab versus sunitinib in advanced renalcell carcinoma. N Engl J Med 378(14): 1277-1290, 2018. PMID: 29562145. DOI: $10.1056 /$ NEJMoa1712126

2 Rini BI, Plimack ER, Stus V, Gafanov R, Hawkins R, Nosov D, Pouliot F, Alekseev B, Soulières D, Melichar B, Vynnychenko I, Kryzhanivska A, Bondarenko I, Azevedo SJ, Borchiellini D, Szczylik C, Markus M, McDermott RS, Bedke J, Tartas S, Chang YH, Tamada S, Shou Q, Perini RF, Chen M, Atkins MB, Powles $\mathrm{T}$ and KEYNOTE-426 Investigators: Pembrolizumab plus axitinib versus sunitinib for advanced renal-cell carcinoma. N Engl J Med 380(12): 1116-1127, 2019. PMID: 30779529. DOI: $10.1056 /$ NEJMoa1816714

3 Choueiri TK, Powles T, Burotto M, Escudier B, Bourlon MT, Zurawski B, Oyervides Juárez VM, Hsieh JJ, Basso U, Shah AY, Suárez C, Hamzaj A, Goh JC, Barrios C, Richardet M, Porta C, Kowalyszyn R, Feregrino JP, Żołnierek J, Pook D, Kessler ER, Tomita Y, Mizuno R, Bedke J, Zhang J, Maurer MA, Simsek B, Ejzykowicz F, Schwab GM, Apolo AB, Motzer RJ and CheckMate 9ER Investigators: Nivolumab plus cabozantinib versus sunitinib for advanced renal-cell carcinoma. N Engl J Med 384(9): 829-841, 2021. PMID: 33657295. DOI: 10.1056/ NEJMoa2026982

4 Motzer RJ, Penkov K, Haanen J, Rini B, Albiges L, Campbell MT, Venugopal B, Kollmannsberger C, Negrier S, Uemura M, Lee JL, Vasiliev A, Miller WH Jr, Gurney H, Schmidinger M, Larkin J, Atkins MB, Bedke J, Alekseev B, Wang J, Mariani M, Robbins PB, Chudnovsky A, Fowst C, Hariharan S, Huang B, di Pietro A and Choueiri TK: Avelumab plus axitinib versus sunitinib for advanced renal-cell carcinoma. N Engl J Med 380(12): 1103-1115, 2019. PMID: 30779531. DOI: 10.1056/NEJMoa1816047

5 NCCN Clinical Practice Guidelines in Oncology (NCCN Guidelines $\left.{ }^{\circledR}\right)$ Kidney Cancer (version 4.2021). Available at: https://www.nccn.org/professionals/physician_gls/pdf/kidney.pdf [Last accessed on May 24, 2021]

6 Escudier B, Porta C, Schmidinger M, Rioux-Leclercq N, Bex A, Khoo V, Grünwald V, Gillessen S, Horwich A and ESMO Guidelines Committee: Renal cell carcinoma: ESMO Clinical Practice Guidelines for diagnosis, treatment and follow-up $\dagger$. Ann Oncol 30(5): 706-720, 2019. PMID: 30788497. DOI: 10.1093/ annonc/mdz056

7 Albiges L, Tannir NM, Burotto M, McDermott D, Plimack ER, Barthélémy P, Porta C, Powles T, Donskov F, George S, Kollmannsberger CK, Gurney H, Grimm MO, Tomita Y, Castellano D, Rini BI, Choueiri TK, Saggi SS, McHenry MB and Motzer RJ: Nivolumab plus ipilimumab versus sunitinib for firstline treatment of advanced renal cell carcinoma: extended 4-year follow-up of the phase III CheckMate 214 trial. ESMO Open 5(6): e001079, 2020. PMID: 33246931. DOI: 10.1136/esmoopen-2020001079

8 Ahrens M, Scheich S, Hartmann A, Bergmann L and IAG-N Interdisciplinary Working Group Kidney Cancer of the German
Cancer Society: Non-clear cell renal cell carcinoma - pathology and treatment options. Oncol Res Treat 42(3): 128-135, 2019. PMID: 30799404. DOI: 10.1159/000495366

9 Gupta R, Ornstein MC, Li H, Allman KD, Wood LS, Gilligan T, Garcia JA, Merveldt DV, Hammers HJ and Rini BI: Clinical activity of ipilimumab plus nivolumab in patients with metastatic non-clear cell renal cell carcinoma. Clin Genitourin Cancer 18(6): 429-435, 2020. PMID: 32800717. DOI: 10.1016/j.clgc.2019.11.012

10 McKay RR, Bossé D, Xie W, Wankowicz SAM, Flaifel A, Brandao R, Lalani AA, Martini DJ, Wei XX, Braun DA, Van Allen E, Castellano D, De Velasco G, Wells JC, Heng DY, Fay AP, Schutz FA, Hsu J, Pal SK, Lee JL, Hsieh JJ, Harshman LC, Signoretti S, Motzer RJ, Feldman D and Choueiri TK: The clinical activity of PD-1/PD-L1 inhibitors in metastatic non-clear cell renal cell carcinoma. Cancer Immunol Res 6(7): 758-765, 2018. PMID: 29748390. DOI: 10.1158/2326-6066.CIR-17-0475

11 Tachibana H, Kondo T, Ishihara H, Fukuda H, Yoshida K, Takagi T, Izuka J, Kobayashi H and Tanabe K: Modest efficacy of nivolumab plus ipilimumab in patients with papillary renal cell carcinoma. Jpn J Clin Oncol 51(4): 646-653, 2021. PMID: 33212488. DOI: $10.1093 / \mathrm{jjco} / \mathrm{hyaa} 229$

12 Eisenhauer EA, Therasse P, Bogaerts J, Schwartz LH, Sargent D, Ford R, Dancey J, Arbuck S, Gwyther S, Mooney M, Rubinstein L, Shankar L, Dodd L, Kaplan R, Lacombe D and Verweij J: New response evaluation criteria in solid tumours: revised RECIST guideline (version 1.1). Eur J Cancer 45(2): 228-247, 2009. PMID: 19097774. DOI: 10.1016/j.ejca.2008.10.026

13 Ahrens M, Escudier B, Boleti E, Grimm M, Gross-goupil M, Barthelemy P, Gravis G, Bedke J, Ivanyi P, Panic A, Zschaebitz S, Negrier S, Mellado B, Biel A, Waddell T, Maroto P, Retz M, Boegemann M, Hartmann A and Bergmann L: A randomized phase II study of nivolumab plus ipilimumab versus standard of care in previously untreated and advanced non-clear cell renal cell carcinoma (SUNIFORECAST). Journal of Clinical Oncology 38(15 Suppl): TPS5103-TPS5103, 2020. DOI: 10.1200/JCO.2020.38.15_suppl.TPS5103

14 Lee C, Voss M, Carlo M, Chen Y, Reznik E, Knezevic A, Lefkowitz R, Shapnik N, Tassone D, Dadoun C, Shah N, Owens C, Mchugh D, Aggen D, Laccetti A, Kotecha R, Feldman D and Motzer R: Nivolumab plus cabozantinib in patients with nonclear cell renal cell carcinoma: Results of a phase 2 trial. Journal of Clinical Oncology 39(15 Suppl): 4509-4509, 2021. DOI: 10.1200/JCO.2021.39.15_suppl.4509

15 Geynisman DM and Plimack ER: Systemic therapy for advanced non-clear-cell renal cell carcinoma: slow but definite progress. Eur Urol 80(2): 171-173, 2021. PMID: 33972094. DOI: 10.1016/j.eururo.2021.04.031

16 Topalian SL, Hodi FS, Brahmer JR, Gettinger SN, Smith DC, McDermott DF, Powderly JD, Carvajal RD, Sosman JA, Atkins MB, Leming PD, Spigel DR, Antonia SJ, Horn L, Drake CG, Pardoll DM, Chen L, Sharfman WH, Anders RA, Taube JM, McMiller TL, Xu H, Korman AJ, Jure-Kunkel M, Agrawal S, McDonald D, Kollia GD, Gupta A, Wigginton JM and Sznol M: Safety, activity, and immune correlates of anti-PD-1 antibody in cancer. N Engl J Med 366(26): 2443-2454, 2012. PMID: 22658127. DOI: 10.1056/NEJMoa1200690

17 Gatalica Z, Snyder C, Maney T, Ghazalpour A, Holterman DA, Xiao N, Overberg P, Rose I, Basu GD, Vranic S, Lynch HT, Von Hoff DD and Hamid O: Programmed cell death 1 (PD-1) and its ligand (PD-L1) in common cancers and their correlation with 
molecular cancer type. Cancer Epidemiol Biomarkers Prev 23(12): 2965-2970, 2014. PMID: 25392179. DOI: 10.1158/1055-9965.EPI14-0654

18 Joseph RW, Millis SZ, Carballido EM, Bryant D, Gatalica Z, Reddy S, Bryce AH, Vogelzang NJ, Stanton ML, Castle EP and Ho TH: PD-1 and PD-L1 expression in renal cell carcinoma with sarcomatoid differentiation. Cancer Immunol Res 3(12): 13031307, 2015. PMID: 26307625. DOI: 10.1158/2326-6066.CIR$15-0150$

19 Tucker MD and Rini BI: Predicting response to immunotherapy in metastatic renal cell carcinoma. Cancers (Basel) 12(9): 2662, 2020. PMID: 32961934. DOI: 10.3390/cancers12092662

20 Jilaveanu LB, Shuch B, Zito CR, Parisi F, Barr M, Kluger Y, Chen L and Kluger HM: PD-L1 Expression in Clear Cell Renal Cell Carcinoma: An Analysis of Nephrectomy and Sites of Metastases. J Cancer 5(3): 166-172, 2014. PMID: 24563671. DOI: $10.7150 /$ jca. 8167

21 Raimondi A, Sepe P, Zattarin E, Mennitto A, Stellato M, Claps M, Guadalupi V, Verzoni E, de Braud F and Procopio G: Predictive biomarkers of response to immunotherapy in metastatic renal cell cancer. Front Oncol 10: 1644, 2020. PMID: 32903369. DOI: $10.3389 /$ fonc.2020.01644

22 Zoumpourlis P, Genovese G, Tannir NM and Msaouel P: Systemic therapies for the management of non-clear cell renal cell carcinoma: What works, what doesn't, and what the future holds. Clin Genitourin Cancer 19(2): 103-116, 2021. PMID: 33358151. DOI: 10.1016/j.clgc.2020.11.005
23 Blank CU, Haanen JB, Ribas A and Schumacher TN: Cancer immunology. The "cancer immunogram". Science 352(6286): 658-660, 2016. PMID: 27151852. DOI: 10.1126/science.aaf2834

24 Malouf GG, Joseph RW, Shah AY and Tannir NM: Non-clear cell renal cell carcinomas: biological insights and therapeutic challenges and opportunities. Clin Adv Hematol Oncol 15(5): 409-418, 2017. PMID: 28591094.

25 Kato T, Nagahara A, Kawamura N, Nakata W, Soda T, Matsuzaki K, Hatano K, Kawashima A, Ujike T, Imamura R, Nishimura K, Takada S, Tsujihata M, Yamaguchi S, Takao T, Nakai Y, Nakayama M, Nonomura N and Uemura M: Realworld outcomes of tyrosine kinase inhibitors immediately after immune checkpoint inhibitors in renal cell carcinoma. Anticancer Res 41(11): 5811-5816, 2021. PMID: 34732455. DOI: $10.21873 /$ anticanres. 15398
Received November 24, 2021

Revised December 16, 2021

Accepted December 23, 2021 